\title{
AGLOMERAÇÃO URBANA DO SUL BRASIL, EXPANSÃO URBANA: 1990 a 2011
}

\author{
URBAN AGGLOMERATION OF THE SOUTH \\ OF BRAZIL, URBAN EXPANSION: 1991 TO 2011 \\ AGLOMERACIÓN URBANA DEL SUR \\ DE BRASIL, EXPANSIÓN URBANA:1990 A 2011
}

\section{Claure Morrone Parfitt}

Doutora em Planejamento Urbano e Regional Docente do Curso de Bacharelado em Gestão Ambiental do Centro de Integração do MERCOSUL e do curso de Especialização em Gestão Pública e Desenvolvimento Regional ambos da Universidade Federal de Pelotas. Rua Andrade Neves,1529Pelotas, Rio Grande do Sul Brasil- CEP 96020-080.

E.mail: claurem.parfitt@gmail.com

\section{RESUMO}

A formação de aglomerações urbanas metropolitanas e não metropolitanas consistem em manifestações do processo de urbanização brasileiro. Localizada no estado do Rio Grande do Sul a Aglomeração Urbana do Sul é formada pelos municípios de Pelotas, Capão do Leão, Arroio do Padre, Rio Grande e São José do Norte. Nesse contexto, no período de 2006 a 2011, ocorreram no local transformações socioterritoriais e econômicas a partir do estabelecimento de nova infraestrutura; (um pólo naval) que veio a dinamizar o território com a implementação atividades produtivas ligadas à globalização. Este trabalho objetivou investigar a expansão urbana da Aglomeração Urbana do Sul no período de 1990 a 2011. Para análise foram utilizadas imagens LANDSAT 5 do Sensor ThematicMapper (TM). Os dados foram processados nos softwares Spring e ArcGIS. Observa-se no sistema, tendências de aglomeração e dispersão; a formação de vazios urbanos e a expansão urbana seguindo as vias de transporte inter e intra urbano.

Palavras chave: Aglomeração Urbana do Sul, Brasil, Expansão urbana. 


\section{ABSTRACT}

The formation of metropolitan and non-metropolitan urban agglomerations consists of manifestations of Brazilian urbanization process. Located in the state of Rio Grande do Sul, the South Urban Agglomeration is formed by the cities of Pelotas, Capão do Leão, Arroio do Padre, Rio Grande and São José do Norte. In this context, between 2006 and 2011, socio-territorial and economic transformations have occurred from the establishment of a new structure (a naval hub) which stimulated the region with the implementation of productive activities linked to globalization. We investigated the urban sprawl of the South Urban Agglomeration between 1990 and 2011. We used LANDSAT 5 and ThematicMapper (TM) sensor images in the analyses. Data was processed using Spring and ArcGIS software. Tendencies of agglomeration and dispersion could be observed in the system; the formation of urban empty spaces and the urban sprawl following interurban and intraurban transport ways.

Keywords: South Urban Agglomeration, Brazil, Urban Expantion

\section{RESUMEN}

El proceso de urbanización brasileño es basado en la formación de aglomeraciones metropolitanas e no metropolitanas. La Aglomeración Urbana del Sur se encuentra en el estado de Rio Grande do Sul, compuesta por los departamentos de Pelotas, Capão do Leão, Arroio do Padre, Rio Grande e São José do Norte. En el periodo 2006 a 2011 hubo transformaciones socio-territoriales e económicas debido al establecimiento de una nueva infraestructura. El polo naval de Rio Grande acelero la implementación de actividades productivas relacionadas a la globalización. Este trabajo ha investigado la expansión urbana de la Aglomeración Urbana del Sur en el período 1990 a 2011 considerando imágenes del sensor Thematic Mapper (TM) a bordo del satélite LANDSTA 5. Los datos fueron procesados em software específicos, como Spring e ArcGIS. Como resultado, se observaron tendencias de aglomeración y dispersión; la formación de vacíos urbanos y la expansión urbana influenciada por las vías de transporte entre complejos urbanos y en su interior.

Palabras clave: Aglomeración Urbana del Sur; Brasil; Expansión urbana 


\section{INTRODUÇÃO}

Nas últimas décadas, as cidades passaram por grandes transformações a partir do processo de globalização, fato que proporcionou sua reestruturação econômica e produtiva (SASSEN, 1998). Nesse contexto o Estado tende a reduzir seu papel na produção da espacialidade urbana e o mercado passa a existir como mecanismo coordenador da produção do espaço urbano (ABRAMO, 2007).

Um tema constante nas análises territoriais atuais é o da dispersão e ou concentração das aglomerações urbanas. Assim, tanto se fala de tendências de dispersão das atividades e da população no território como no momento seguinte, se assinala novas tendências de concentração e centralização (MARTNER, 2016).

Nessa ótica, a concentração territorial traz em si contradições, próprias do sistema capitalista, que levam a propiciar forças contrárias, ou tendências à dispersão. Segundo Pradilla (1984) essas desvantagens da aglomeração provem da anarquia que gera, no crescimento das cidades, o caráter privado da propriedade, dos meios de produção e da apropriação, da produção social e, com isso o caráter individual das decisões de apropriação do solo e da produção imobiliária.

No Brasil esse processo ocorreu, e ocorre nas grandes cidades, mas também, nas de porte médio, com população entre 100 mil e 500 mil habitantes que cresceram a taxas maiores do que as metrópoles, nos anos 80 e 90 (4,8\% contra 1,3\%). A aceleração extraordinária do crescimento das cidades de porte médio, e das cidades litorâneas, de um modo geral, exige evidentemente tensão devido às consequências socioambientais decorrentes da velocidade do processo de urbanização (Maricato, 2000).

Assim a expansão do espaço urbano relacionada à intensa urbanização, provocou no país a formação de loteamentos regulares (que seguem a Lei Federal 6766/79), específicos para a população com maior poder aquisitivo, pelos loteamentos irregulares ou clandestinos, bem como, o surgimento de favelas; áreas precárias de habitação desprovidas de infraestrutura , normalmente em invasões.

Nesse sentido cabe assinalar que no Brasil existem escassos trabalhos desenvolvidos sobre aglomerações urbanas em torno de cidades médias podendo-se citar os de Miyazaki (2005) Soares (2005), Moura (2005) Braga (2005) Ojima (2007) que tratam desse tema, menos ainda, ou nada foi encontrado sobre a expansão desse sistema de cidades. A literatura abarca principalmente o estudo das metrópoles ou dos grandes centros urbanos, portanto pouco tem se avançado no conhecimento desses espaços.

a 
Esta pesquisa tem como objetivo investigar a expansão urbana na Aglomeração Urbana do Sul localizada no estado do Rio Grande do Sul, no período de 1990 a 2011, Sua importância está em poder servir de base para planejamento, bem como, gestão urbana e regional.

Com o intuito de desenvolver o anterior, o trabalho se divide em quatro seções ademais da introdução e conclusão. A segunda seção, após a introdução aborda o referencial teórico da pesquisa ou, Estruturas urbanas territoriais brasileiras, As aglomerações Urbanas e a Expansão urbana no Brasil. Na terceira, Materiais e métodos e na quarta resultados e discussão.

\section{ESTRUTURAS TERRITORIAIS URBANAS BRASILEIRAS}

De acordo com Matos (2000) é provável que o processo de concentração econômica e demográfica brasileiro tenha atingido seu ponto máximo na década de 1970.

Nessa época, Davidovich e Lima (1975), com base em critérios demográficos e econômicos, distinguiram, no país, uma hierarquia de áreas urbanas compreendendo aglomerações resultantes da expansão de uma cidade central; aglomerações por processo de conurbação; aglomerações de cidades geminadas; e aglomerações sem espaço urbanizado contínuo. Assim, nessa hierarquia, aparecem as aglomerações metropolitanas, de caráter nacional e regional, áreas metropolitanas incipientes e aglomerações submetropolitanas. Abaixo do nível metropolitano, as autoras identificaram aglomerados de três tipos: 1) aqueles com uma cidade central, 2) outros formados por processo de conurbação e 3) os que se organizam a partir de cidades geminadas. Por fim, aparecem também as aglomerações sem espaço urbanizado contínuo. O trabalho das autoras tornou-se referencia para estudos subsequentes sobre o mesmo tema. Nesse contexto em 1985, Redwood postulou a tese da desconcentração das principais áreas metropolitanas a favor de áreas urbanas imediatamente próximas e cidades médias. O crescimento das áreas metropolitanas diminuía, enquanto as cidades com população entre 100 e 500 mil habitantes acolhiam o processo de urbanização.

De acordo com Soares (2005) as últimas décadas tem se caracterizado por profundas mudanças nas estruturas territoriais urbanas brasileiras sendo que a desconcentração metropolitana é um dos mais importantes processos espaciais no redesenho do território do país. Verifica-se também um dinamismo sócioespacial nas aglomerações formadas no entorno de cidades médias no interior do país. Com as economias dos núcleos metropolitanos cada vez mais vinculadas ao setor terciário, as cidades médias estão emergindo com o novo papel de centros industriais. Na última década, a indústria brasileira cresceu nessas cidades e nos espaços peri metropolitanos convertendo esses núcleos urbanos em polos de atração de migrações internas e inter-regionais, como no caso aqui estudado. 
Assim, vale destacar que as cidades médias têm-se tornado um objeto de estudo importante para diferentes pesquisadores da atualidade. Questões estruturais da economia nacional, formas de espacialização dos fluxos econômicos e demográficos, bem como as transformações de caráter intraurbano nas grandes metrópoles têm potenciado o reavivamento dessa categoria de cidade na rede de localidades centrais do Brasil. Nessa ótica, um dos aspectos que mais têm contribuído para o aumento das pesquisas na área é o processo de desconcentração que o país vem vivendo (RAMOS; MATOS, 2011)

Nesse sentido, essas cidades (médias) estão relacionadas com as Aglomerações Urbanas que foram formalmente instituídas no Brasil na Constituição Federal de 1988. A partir daí foi dado um passo importante rumo à descentralização política quanto o aspecto metropolitano. O tema foi abordado no parágrafo 3 do art. 25 onde mediante lei complementar poder-seiam “ instituir Regiões Metropolitanas, Aglomerações Urbanas e Microrregiões constituídas por agrupamentos de municípios limítrofes para integrar a organização a organização, o planejamento e a execução de funções públicas de interesse comum" (BRASIL,1988).

\section{AS AGLOMERAÇÕES URBANAS}

No entendimento de Souza (2005), Aglomeração Urbana corresponde a uma espacialidade composta por uma ou mais cidades, cujos vínculos passaram a ser muito fortes, engendrando fluxos de diversas naturezas, sendo, o mais significativo, o de trabalhadores assalariados que, por residirem em uma cidade e exercerem sua profissão em outra, acabam promovendo o que se denomina movimentos pendulares.

Já para Moura e Ultramari (1994, p. 125), uma aglomeração urbana "representa o espaço de comutação diária entre cidades, isto é, o desenvolvimento de relações interdependentes entre duas ou mais áreas urbanas, compondo um fenômeno único".

Não obstante, Moura e Ultramari (1994) afirmam que há relação entre a espacialidade de uma aglomeração urbana e a área polarizada pelo núcleo desta aglomeração. Comentando os resultados do estudo Região de Influência das Cidades (REGIC), eles asseveram que o espaço polarizado por um núcleo qualquer pode ser muito grande, no entanto, relatam que a definição dos limites de uma aglomeração urbana "não deve refletir apenas o alcance de uma extensa polarização, mas, antes, a forma complexa que tal polarização configura" (MOURA; ULTRAMARI, 1994, p. 126).

É importante ressaltar que há quem assegure que uma aglomeração urbana reflita apenas um fenômeno físico-territorial, expresso pela continuidade de manchas urbanas, ou seja, pela conurbação (MOURA; ULTRAMARI, 1994), porém tanto Moura e Ultramari (1994) 
quanto Souza (2005) e Soares (1968) concordam que a conurbação não é imprescindível para caracterizar uma aglomeração urbana.

Assim, o conceito de aglomeração urbana está bastante vinculado ao de metrópole, o qual nos fala de formações urbanas relativamente extensas, que abrangem mais de um município. Esta categoria espacial pressupõe a existência de uma cidade principal que organiza, econômica e funcionalmente, localidades periféricas próximas. Em consequência deve surgir uma densa rede urbana onde se instalam atividades industriais, comerciais e de serviço, concentrando capital, força de trabalho e poder político. (MATOS, 2000).

Por aglomeração urbana, portanto, entende-se tratar-se de um espaço regional dotado de intensas e recíprocas relações sociais e econômicas entre as unidades políticoadministrativas que o compõem. Um dos elementos concretos que representam a possibilidade de caracterização da aglomeração urbana é o movimento pendular, pois sua natureza contempla o transbordamento ou projeção da população e atividades de uma cidade, ou município, sobre áreas vizinhas.

\section{A EXPANSÃO URBANA NO BRASIL}

A expansão do espaço urbano nas cidades brasileiras ocorre basicamente das seguintes formas: a partir de loteamentos formais, de modo celular, lote a lote, através de ocupações informais pelos loteamentos irregulares ou clandestinos (que não seguem a lei 6766, ou lei de loteamentos) ou favelas: áreas precárias de habitação irregular (MAIA, 2010),

Nessa ótica, segundo Barros (1999) a expansão por loteamentos em relação à morfologia (forma do tecido urbano) dentro do contexto geral do crescimento urbano pode ser considerada um crescimento semiplanejado, ou seja, é projetado isoladamente sem considerar o crescimento global, o que resulta normalmente, em uma descontinuidade do tecido urbano.

A expansão urbana assim está vinculada à transformação interna da cidade, sua produção encontra-se inserida na dinâmica do mercado de produção do espaço urbano. Dessa forma considerando que o fator impulsionador de toda a produção é a busca pelo maior lucro a problemática central da produção das expansões por loteamentos parece estar na rentabilidade (BARROS, 1999). Sobre o assunto Ribeiro (1997) sugere que a urbanização da periferia somente torna-se atrativa caso os custos adicionais sejam inferiores ao capital empregado na compra da mesma extensão de solo nas zonas habitualmente destinadas ao submercado que ele pretende atingir.

Dessa forma, para Villaça (1998) os terrenos da periferia teriam menos trabalho social incorporado em sua produção do que os centrais. Nesse contexto, o ambiente periférico 
é disperso e pouco construído, sua valorização é menor tanto em relação ao valor, quanto ao valor de uso e valor social.

No processo de produção do espaço urbano por loteamentos observam-se ações especulativas específicas, que os empreendedores lançam mão podendo-se identificar basicamente duas formas: 1) a invenção de macrolocalização Harvey (1985) e 2) a criação de vazios urbanos. A primeira, invenção de macrolocalização está relacionada ao que poderia ser chamado de potencial de crescimento. Ou a localização de todo o loteamento em relação ao sistema urbano. A presença de certos elementos como a existência de um núcleo comercial, ou de um condomínio residencial de classe alta conferiria à área da cidade um status que poderia ser identificado como potencializador de crescimento. Nessa ótica, haveria uma invenção de macrolocalização no sentido de promover não apenas uma área específica da cidade, mas em criar, o interesse no crescimento de uma grande área e possibilidades de estabelecer um vetor de crescimento à área loteada a partir de características ocupacionais em nível de macrolocalização. Já a segunda, criação de vazios urbanos que parece ter ocorrência comum nas cidades brasileiras de acordo com Santos (1996) e Clichevsky (1980) acontecendo da seguinte forma: Considerando que os vazios urbanos entre loteamentos seriam mais lucrativos que as outras glebas por serem áreas mais valorizadas pelo fato de já contarem previamente com infraestrutura instalada, esta situação também seria uma ação especulativa. Barros (1999) considera que esse artifício consistiria basicamente em uma retenção de terrenos mais elaborada, no sentido de que não se trata apenas de uma espera pela valorização, mas da invenção dessa valorização através de um "crescimento forçado" ou seja de outro loteamento. Esse processo especulativo influencia diretamente na localização de loteamentos periféricos (ligados à propriedade da terra). A invenção de vazios urbanos faria com que terras não loteadas se beneficiassem do crescimento periférico e, portanto, da valorização do preço do solo desencadeado pelo crescimento e pela ação da infraestrutura a qual seria levada através dele barateando seus futuros custos de urbanização.

No que se refere aos assentamentos informais estes se constituem segundo a UN HABITAT (2002) em uma comunidade de indivíduos que vivem em terrenos sem direito ou certificado de posse, com domicílios normalmente situados em áreas inadequadas sob ponto de vista de risco natural, industrial e próximos a vias de circulação intensa ou mesmo áreas públicas apresentando precariedade de pelo menos um dos serviços essenciais; água saneamento, com domicílios que apresentam estruturas temporárias ou dilapidadas; precariedade dos materiais de construção e discordância com os códigos de construção.

De acordo com Abramo (2007) a cidade popular ou informal na América latina não é fenômeno recente, e podendo-se identificar processos de produção de territórios 
populares urbanos à margem das regras e das normas oficiais desde o tempo da colônia em praticamente todos os países de colonização portuguesa e espanhola. Contudo, o processo de urbanização acelerado do século XX tem um papel determinante na amplificação desse processo de produção de cidades populares informais.

Davis (2006) comenta que a maioria dos pobres do mundo não mora mais em bairros pobres no centro da cidade. Desde 1970, o maior quinhão do crescimento populacional urbano mundial foi absorvido pelas comunidades faveladas das periferias das cidades do terceiro mundo. Assim, a horizontalização das cidades pobres costuma ser tão espantosa quanto seu crescimento populacional.

Milton Santos (1981) afirmou que os habitantes das favelas são predominantemente imigrantes recentes da cidade e que não possuem renda e qualificação profissional e, por isso, se fixam em terrenos de pouco valor aquisitivo, impróprios para a construção e localizados em áreas periféricas longe do centro de aglomeração. E destaca que no decorrer do tempo, as cidades se expandem e as favelas que resistem esse processo acabam permanecendo próximo ao centro da cidade.

De acordo com Grostein (2001), Maricato (2000), a cidade informal, no Brasil cresce exponencialmente na ilegalidade urbana, sem atributos de urbanidade, exacerbando as diferenças socioambientais.

Para concluir a expansão das cidades brasileiras conforme Santos (1992) deu-se de forma espraiada desde os anos 80 do século XX configurando um tipo de cidade que se caracteriza pela periferização, fragmentação e dispersão.

\section{MATERIAIS E MÉTODOS}

\section{A Aglomeração Urbana do Sul: caracterização da área de estudo}

O Rio Grande do Sul é um estado que se localiza no extremo sul do Brasil, fazendo fronteira com Uruguai e Argentina. Tem uma população de mais de 10 milhões de habitantes e uma área territorial de $282 \mathrm{mil} \mathrm{Km}^{2}$. Possui uma hierarquia urbana comandada por Porto Alegre, e seus municípios de entorno que formam a Região Metropolitana de Porto Alegre (RMPA).Existem em seu território ainda as seguintes aglomerações urbanas: Aglomeração Urbana de Caxias do Sul (Aglomeração Urbana do Nordeste- AUNE); Pelotas- Rio Grande (Aglomeração Urbana do Sul- AUSUL) e a Aglomeração Urbana do Litoral Norte (AU Norte).Há também duas aglomerações descontínuas em que as cidades de Passo Fundo e Santa Maria são seu núcleo Figura ( 1 e 2 ) 
Nesse contexto, a primeira aglomeração urbana institucionalizada no Estado do Rio Grande do Sul foi a Aglomeração Urbana de Pelotas, criada por lei complementar em 1990, inicialmente com os Municípios de Pelotas e Capão do Leão, aos quais foram acrescentados, em 2002, a partir da Lei Complementar 271 aprovada pela Assembléia Legislativa acrescidos os Municípios de Rio Grande, Arroio do Padre e São José do Norte denominada Aglomeração Urbana do Sul. Figura (1)

O estudo de Davidovich e Lima (1975) sobre o fenômeno aglomerativo urbano do País já havia identificado como aglomeração o conjunto Pelotas-Rio Grande, que foi classificado no agrupamento das aglomerações sem espaço urbanizado contínuo.

Nessa ótica, Pelotas e Rio Grande, cidades de porte médio são os principais núcleos urbanos da metade sul do Rio Grande do Sul com população de 306.193 e 189.429 habitantes respectivamente ficando distantes $60 \mathrm{Km}$ uma da outra. A Aglomeração Urbana do Sul apresenta dessa forma, uma estrutura bipolar, Soares (2005) contando com mais de 600 mil habitantes.

Em décadas passadas Pelotas e Rio Grande apresentaram perda de seu dinamismo industrial, fato que se reverteu a partir de 2005 a partir de transformações no setor econômico de construção civil e infraestrutura gerados pelo dinamismo da economia do polo industrial do município de Rio Grande principalmente pela instalação do polo naval.

Assim, o estabelecimento do Pólo Naval e Offshore em Rio Grande permitiu que forças impulsionadoras de seu desenvolvimento se manifestassem. A vinda de industriais diversas para a cidade acarretou um importante crescimento da população, fato que exigiu novas áreas residenciais para a sua localização e conseqüente expansão urbana. (Domingues, 2009). Os impactos socioeconômicos e sócioespaciais se manifestaram no dia-a-dia da cidade e região, apontando para problemas funcionais, tanto nas áreas de logística intra e inter-urbana, como na habitação, saúde e educação. Outro fato relevante foi a importação de mão-de-obra qualificada de outras regiões do estado e, principalmente, do centro do país provocando "inflação de demanda local” por bens e serviços (DOMINGUES, 2009). 
Figura 1 - Aglomeração Urbana do Sul

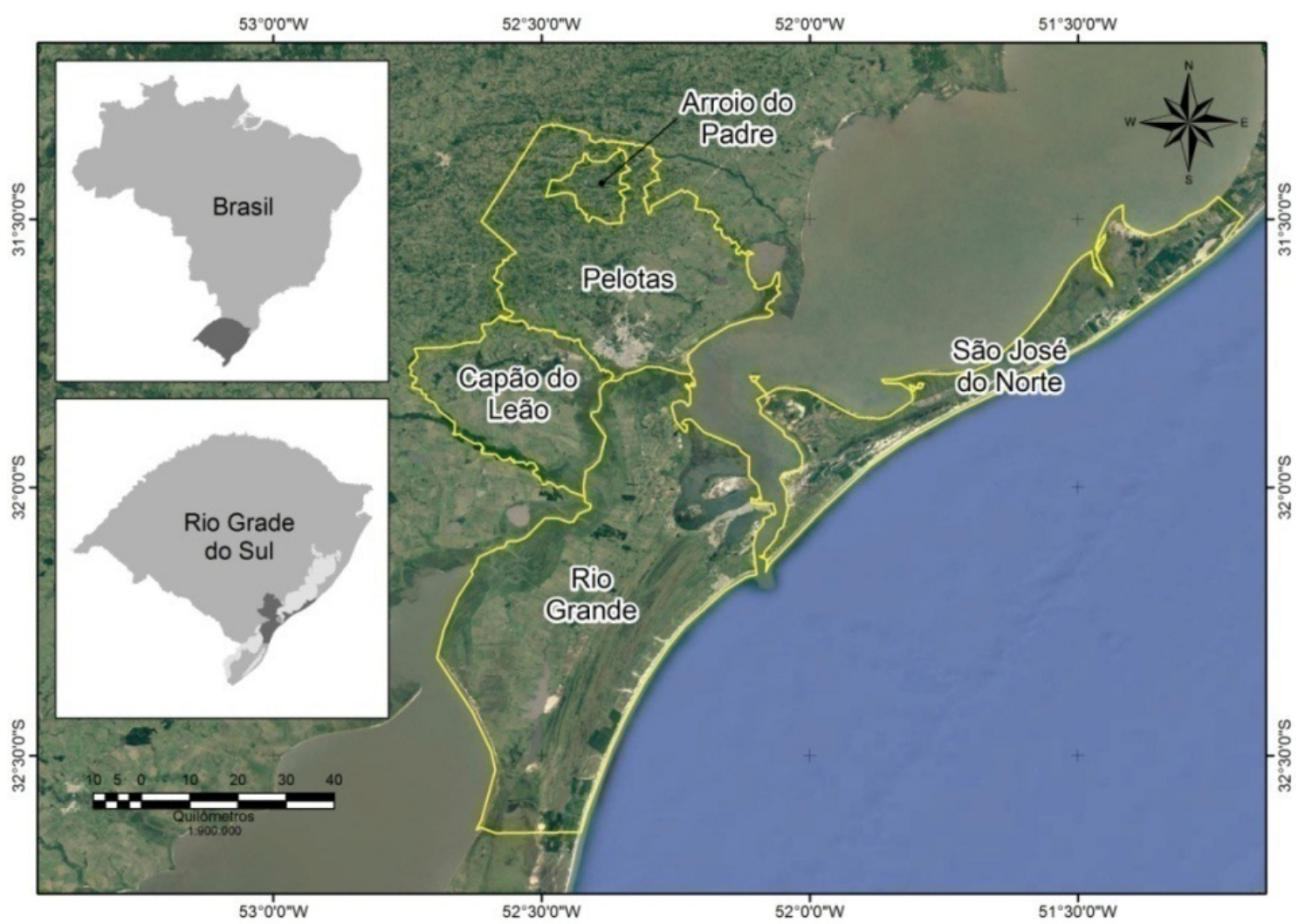

Fonte: Elaboração própria a partir de imagem Google Earth ${ }^{\circledR}$

Figura 2 - Figura 2 Aglomerações Urbanas no Rio Grande do Sul

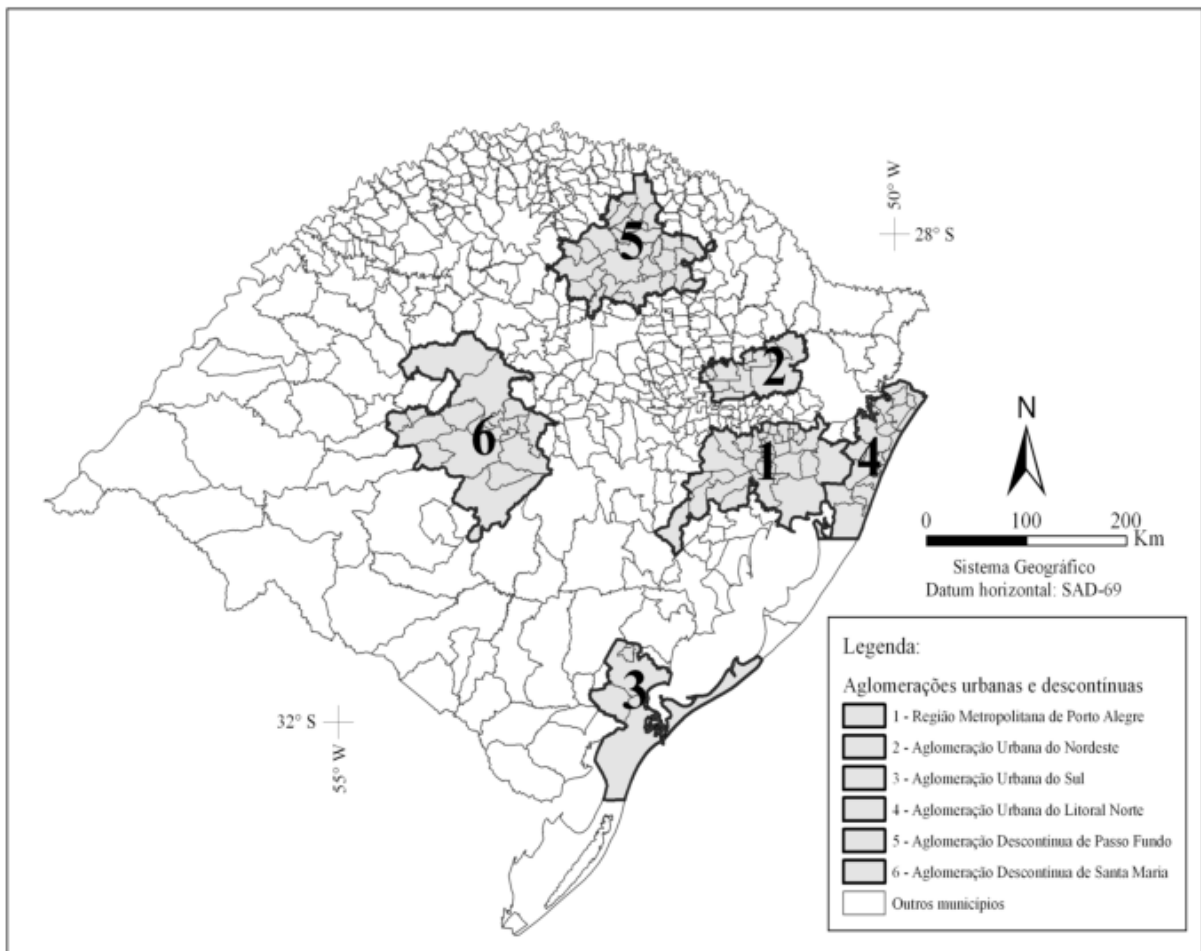

Fonte: cartografia IBGE. Elaborado pelo Neru- FEE 2009 
O início da povoação de Pelotas data de 1780. Atualmente consiste no polo comercial e de serviços da aglomeração. Possui importante setor agro alimentar (beneficiamento de arroz, frigoríficos e conservas e também importante patrimônio arquitetônico cultural de forte influencia europeia sendo uma dos maiores de estilo eclético do Brasil Em seu estudo, Marques (2007) identificou vários assentamentos precários no centro e na periferia da mancha urbana. O autor estima que em Pelotas viviam 25.633 pessoas em assentamentos precários no ano de 2000, o equivalente a 8,56\% da sua população .Já Rio Grande, a cidade mais antiga do Rio Grande do Sul, teve o início de sua povoação em 1737. Seu centro histórico apresenta edificações representantes da corrente luso-brasileira e eclética. Tem importância devido a seu porto, (o maior do estado) e indústrias pertencentes ao polo naval, bem como, petroquímica, fertilizantes e pescado. Rio Grande tem se destacado em âmbito estadual e nacional ao longo dos últimos anos. Com a ampliação do canal no porto da cidade, novos investimentos deram novo fôlego à economia do município. A cidade conta também com um distrito industrial muito forte, onde opera um polo diversificado com indústrias, de madeira, fertilizantes, alimentos, energia e química, logística, terminais graneleiros e metalúrgica. A pesquisa de Marques (2007) estimou que no ano de 2000, 18,12\% da população de Rio Grande num total de 32.313 pessoas moravam em assentamentos precários. Segundo Souza (2011) essa proporção é elevada se comparada a Região Sul 574.395 pessoas, (4,6 da população total), Região metropolitana de Porto Alegre com 210.510 pessoas (6,02\% da população total) e Pelotas com $(8,56 \%$ da população total) (SOUSA, 2011). Nesse contexto, foram identificados vários setores precários na península que adentra a Lagoa dos Patos (área em amarelo no mapa, e local do primeiro núcleo urbano) (fig.5). Alguns no litoral marítimo (balneário Cassino) e nas áreas que a lagoa faz comunicação com o mar (MARQUES,2007).

Integrantes da aglomeração ainda têm-se três municípios menores. Capão do Leão, Arroio do Padre e São José do Norte.

A base da economia municipal do Capão do Leão (emancipado de Pelotas em 1982) é a agricultura seguida do extrativismo mineral, comércio e indústrias de pequeno, médio e grande porte, e também a prestação de serviços.Já Arroio do Padre é um município que faz parte da bacia hidrográfica do rio Camaquã, criado em de 1996 pela Lei estadual no 10.738 , emancipando-se de Pelotas. A maioria dos moradores é descendente de pomeranos e em várias residencias ainda se fala o dialeto trazido da Pomerania (região histórica da Alemanha, hoje pertencente à Polônia)a economia é dominada pelo setor primário. Destacam-se as plantações de tabaco, milho e verduras. A pecuária leiteira também tem papel importante na sua economia. O município tem como características o minifúndio e a policultura. 
É formado por pequenas propriedades rurais, cada uma em torno de 20 hectares, que são cultivadas com mão-de-obra familiar. Asede de Arroio do Padre apresenta natureza "rururbana" configurando uma forma urbana padrão "espinha de peixe" como as antigas aldeias alemãs rio-grandenses. (WEIMER, 2004).

Por fim, São José do Norte criada pelo Decreto Imperial s/nº de 25 de outubro de 1831. Está localizada na Península de Mostardas, na Bacia do Litoral Médio do Rio Grande do Sul, entre o Oceano Atlântico e a Laguna dos Patos.São José do Norte possui um Centro Histórico com exemplares de interesse histórico-cultural, como imóveis tombados e inventariados. A economia do município baseia-se no cultivo de arroz, o de cebola, ainda a pecuária e pesca e extrativismo vegetal com a extração de resina de Pinus Elliotti, árvore plantada em larga escala ao longo da costa do oceano Atlântico. A economia municipal passa por grandes mudanças tendo como principal fonte de emprego o pólo naval.

É importante ressaltar que o município de Pelotas polariza Capão do Leão (com o qual é conurbado) e Arroio do Padre. Nesse contexto, Rio Grande está diretamente relacionado com São José do Norte. Ainda, que Pelotas e Rio Grande, cidades de médio porte apresentam economia urbana dinâmica ao contrário das cidades menores atualmente observa-se declínio econômico na região, reflexo da situação por que passa o país.

\section{Sistema de informação geográfica e análise multitemporal por meio de imagens orbitais}

Uma das ferramentas que auxilia o manuseio e processamento de informações georreferenciadas são os sistemas de informações geográficas (SIG), compostos por hardwares, softwares e artifícios computacionais que possibilitam a análise espacial, gestão e representação do espaço físico, de fenômenos que nele ocorrem, com a finalidade de coordenar e organizar estes fenômenos através de mapas (CORSEUIL; MADRUGA, 1998); (SANTOS; LOUZADA; EUGENIO, 2010). No contexto se insere o sensoriamento remoto que permite o registro histórico e estudo do meio físico com a ajuda de imagens aéreas ou orbitais (MORAES, 2002).

A maioria das pesquisas focadas para estudos de expansão urbana que consideram técnicas de sensoriamento remoto possuem como principal objetivo a discriminação de áreas urbanas e não urbanas (HAMBURGER;VIEIRA, 2014).No comportamento espectral dos alvos urbanos, não é possível eleger um padrão, pois existem vários tipos de materiais associados(asfalto, concreto, telhas...) conforme relatado por Souza (2012). Esse autor também destaca que imagens com resolução espacial média (10-50 m) apresentam refletância intensa para manchas urbanas, na faixa do visível, sendo relativamente fácil a discriminação de outras coberturas terrestres. As informações sobre as características 
espectrais da paisagem urbana são limitadas, pois a maioria dos estudos são intra-urbanos. Os recursos mais utilizados são fotografias aéreas, que possuem alta resolução espacial (HAMBURGER; VIEIRA, 2014).

Aos efeitos de interpretar os motivos do crescimento, se analisaram parâmetros socioeconômicos (IBGE, 2014), que foram ajustados por interpolação linear, às datas de interesse.

Para o estudo, foram utilizadas imagens do sensor ThematicMapper(TM), a bordo do satélite LANDSAT 5, correspondentes aos anos de 1990, 1996, 2001, 2006 e 2011; que foram conferidas com imagens de alta resolução disponíveis na mídia digital (Google Earth $\left.{ }^{\odot}\right)$.A melhor composição para discriminar o alvo pretendido (área urbana) foi a 345 em RGB, devido a maior variabilidade de tons, texturas e boa discriminação das outras coberturas do solo (SOUZA, 2012;HAMBURGER; VIEIRA, 2014).

As áreas urbanas foram digitalizadas como polígonos no programa SPRING 5.2.6, para evitar erros de inclusão e omissão, frequentes nos classificadores automáticos (D’ ARCO; RUDORFF, 2008). O município de Arroio do Padre constituiu um caso anômalo devido à sua natureza "rururbana" (padrão "espinha de peixe" conforme VASCONCELOS; NOVO, 2014) e recente emancipação. Os polígonos de cada área urbana foram organizados por ano, sendo sobrepostos em diferentes cores, para aprimorar a visualização do crescimento urbano, via o software ArcGis 9.3 (ESRI, 2014).Após a avaliação de áreas, os valores obtidos foram comparados com os dados dos Censos disponíveis nos anos 1991, 2000 e 2010 (IBGE, 2014), sendo interpolados linearmente os valores para os anos de interesse, de maneira a ter coincidência com as datas das imagens.

Quando a vetorização das imagens LANDSAT 5 foi confrontada com as imagens de alta resolução (Google Earth ${ }^{\circledast}$ ), identificou-se confusão nas regiões com ocorrência acentuada de areia, devido à resposta espectral semelhante com a área urbana.

Os períodos foram estabelecidos da seguinte maneira: para dados dos Censos, o primeiro período corresponde ao intervalo entre 1991 e 2000 e o segundo período ao intervalo entre 2000 e 2010; para os resultados das manchas urbanas, o primeiro período equivale ao intervalo entre 1990 e 2001, e o segundo período ao intervalo entre 2001 e 2011.

\section{RESULTADOS E DISCUSSÃO}

A partir dos procedimentos metodológicos, obtiveram-se quatro mapas, referentes às seguintes cidades analisadas; Pelotas, Rio Grande, Capão do Leão e São José do Norte demonstrando seu crescimento espacial. Já a sede do município de Arroio do Padre foi mapeada com o aplicativo Google Earth $\odot$, pelo fato de praticamente não apresentar crescimento no

\section{a}


período. Os dados relativos ao crescimento populacional e renda per capta foram obtidos nos Censos do IBGE (Instituto Brasileiro de Geografia e Estatística) 1991 e 2010 bem como da FEE (Fundação de Economia e Estatística do estado do Rio Grande do Sul).

\section{Pelotas}

A cidade de Pelotas, um dos polos da aglomeração apresentou os seguintes dados de crescimento; No período de 1991 a 2010 a população urbana passa de 265.192 para 306.193 habitantes num acréscimo de 41.001 habitantes ou 15,46 \%. Sua renda per capta passou de $\mathrm{R} \$ 504.76$ reais para $\mathrm{R} \$ 894.35$ reais.

Quanto à expansão da área urbanizada de 1990 a 2011passa de 44,88 Km2 em 1991 para 65,2 Km2 em 2011 observando-se um aumento de 20,31 Km2 ou 45,25\%.

De 2001 a 2011 observa-se o crescimento nas bordas da cidade bem como o processo especulativo da criação de vazios urbanos (figura 3). A expansão acontece seguindo as vias, principalmente nas direções norte, oeste e leste, pois a sul tem-se o canal São Gonçalo. É importante ressaltar que na direção leste, rumo à lagoa dos Patos são identificados loteamentos e condomínios fechados de alto e médio padrão Já na direção norte e oeste, loteamentos de população de médio, menor poder aquisitivo e áreas precárias ou favelas.

Figura 3 - Mapa resultante da vetorização do município de Pelotas, sobreposta a uma imagem do sensor TM pertencente ao satélite LANDSAT 5.

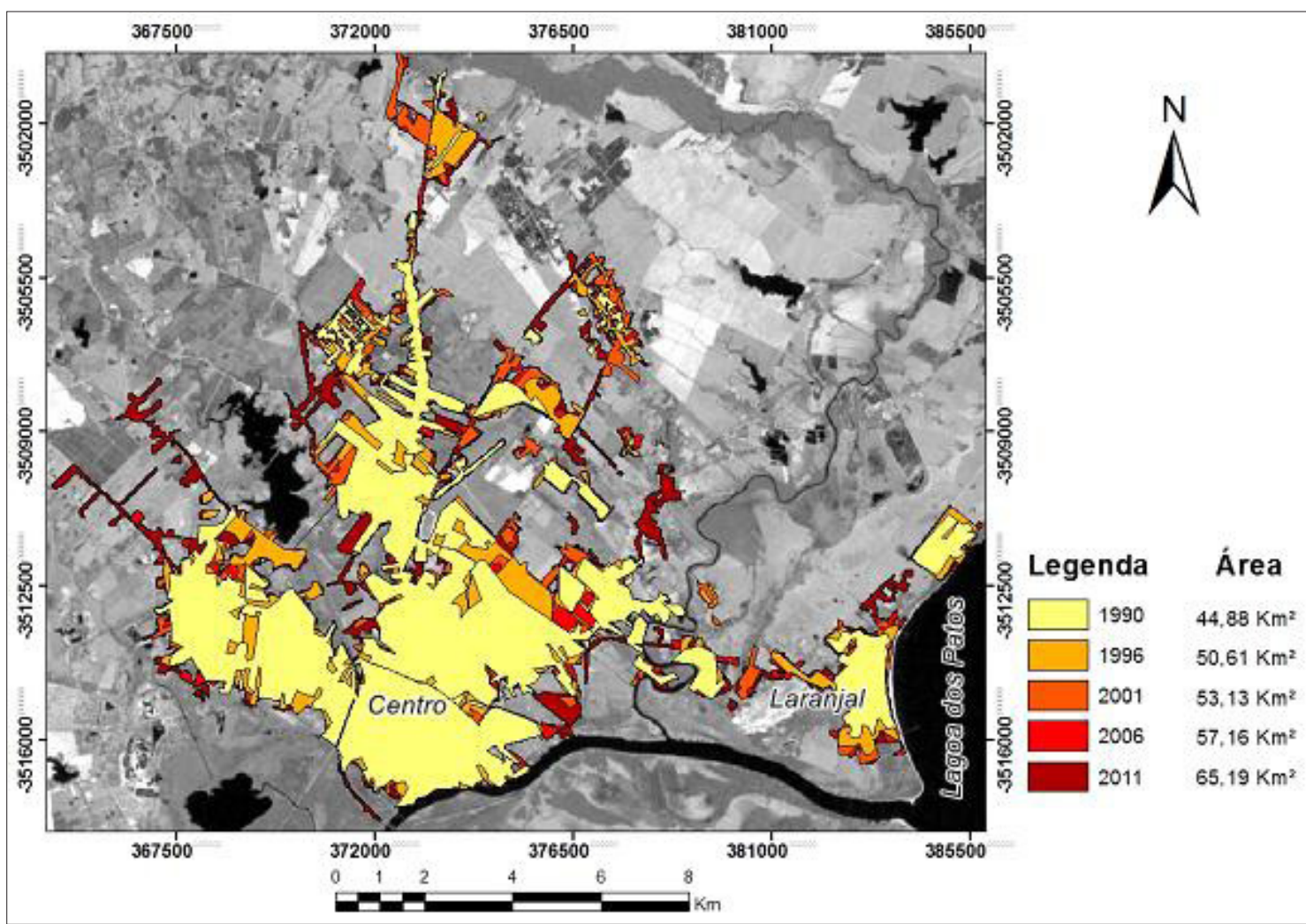

Fonte: Org.: GALLO, B. B., 2014. 


\section{Capão do Leão}

Em Capão do Leão, cidade que se encontra conurbada com Pelotas a situação apresentase da seguinte forma: A população urbana apresenta 16.194 habitantes em 1991 atingindo 22.354 habitantes em 2010 num aumento total de 6160 habitantes ou 38,04\%. A renda per capta de $\mathrm{R}$ \$233,74 em 1991 alcança $\mathrm{R}$ \$ 493,36 em 2010. Já no que se refere à expansão passa de 2,56 km2 em 1991 para 19,02 km2 em 2001 aumentando 16,46 km2 ou 642,9\%.

Figura 4 - Mapa resultante da vetorização do município de Capão do Leão, sobreposta a uma imagem do sensor TM pertencente ao satélite LANDSAT 5

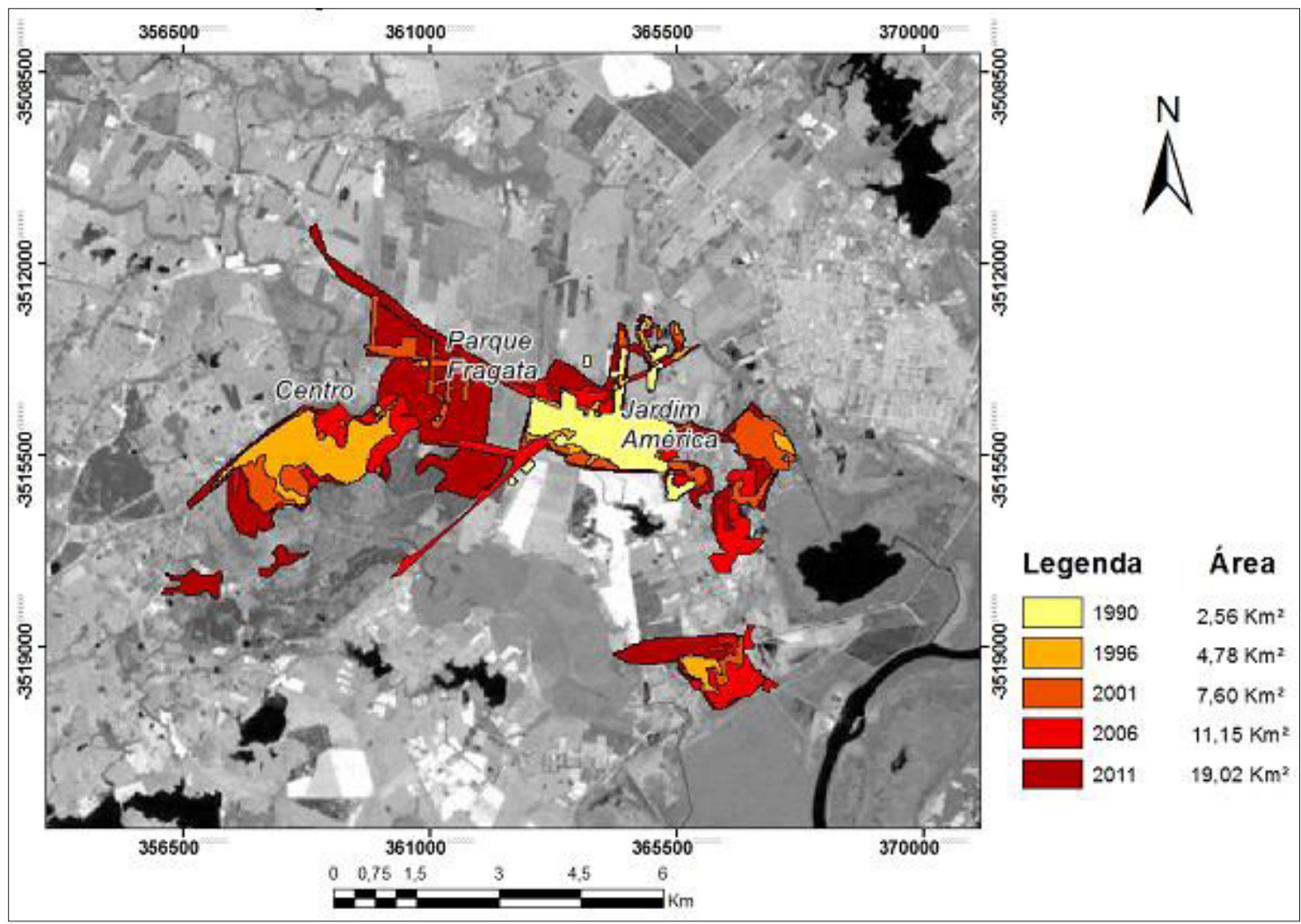

Fonte: Org. GALLO, B. B., 2014.

Nesse contexto, a partir de dados obtidos na prefeitura local, relacionados com os do mapeamento observa-se que embora o primeiro núcleo, tenha sido o centro, Teodósio (em laranja no mapa à esquerda) (figura 4) ele efetivamente foi ocupado em 1996. Já o loteamento Jardim América, que pertencia a Pelotas antes da emancipação do município do Capão do Leão, (em amarelo no mapa) (figura 4) já era ocupado anteriormente a 1990.

Quanto ao Parque Fragata, loteamento conformado por chácaras de lazer com lotes de 15x150 implantado em 1953, somente a partir de 2011 começou a ser efetivamente ocupado de modo irregular, principalmente por pessoas provenientes de municípios da região, como Pelotas, Piratini, Canguçu etc. Constata-se também o fenômeno das invasões em áreas 
públicas, praças e áreas institucionais no loteamento Jardim América. O crescimento da área urbana tanto em população como em extensão deve-se ao fato principalmente de o solo urbano ter menor valor na cidade de Capão do Leão, que a cidade polo da aglomeração; Pelotas e também por estar próximo ao distrito industrial dessa cidade.

\section{Rio Grande}

Para a cidade de Rio Grande, o outro polo da aglomeração, a população urbana em 1991 era 165.025 habitantes; em 2010 atinge 178.825 habitantes num acréscimo de 13.800 habitantes ou 8,36\%. A renda per capta praticamente dobra passa de R 458,75 em 1991 para $\mathrm{R} \$ 859,20$ em 2011, fato esse explicado pelo estabelecimento do polo naval na cidade. A expansão da área urbanizada passa de 23,57 km2 em 1990 para 51,49 km2 em 2011 num total de 27,92 km2 ou 118,45\%. Essa expansão pós 1990 acontece a sudoeste na península que avança na Lagoa dos Patos, na zona portuária, polo naval localizado às margens do canal de ligação da Lagoa dos Patos com o oceano, no balneário Cassino núcleo isolado localizado a sul as margens o Oceano Atlântico que apresenta crescimento contínuo das suas bordas e na Quinta povoação localizada a oeste do centro urbano (figura 5).

E importante salientar que o Cassino, embora seja o principal balneário do Sul do Rio Grande do Sul, para onde no verão aflui a população de muitos de seus municípios tornou-se residência de grande parte da classe média alta local, estudantes da Universidade Federal do Rio Grande (ver núcleo central em amarelo no mapa) (figura 5), bem como de população de classe de baixo poder aquisitivo em sua periferia; bordas paralelas ao Oceano Atlântico. Nesse sentido, a partir de 1996 observa-se a expansão periférica principalmente por parcelamentos irregulares, segundo dados da prefeitura municipal. Já na Quinta identifica-se efetiva expansão a partir de 2001 também por parcelamentos irregulares, segundo dados da prefeitura municipal.

Por fim, nesse processo de expansão observam-se os dois fenômenos anteriormente citados os quais podem ser visualizados na (figura 5) a produção de vazios urbanos e o crescimento a partir dos eixos de transporte tanto intra, como inter urbano. 
Figura 5 - Mapa resultante da vetorização do município de Rio Grande, sobreposta a uma imagem do sensor TM pertencente ao satélite LANDSAT 5

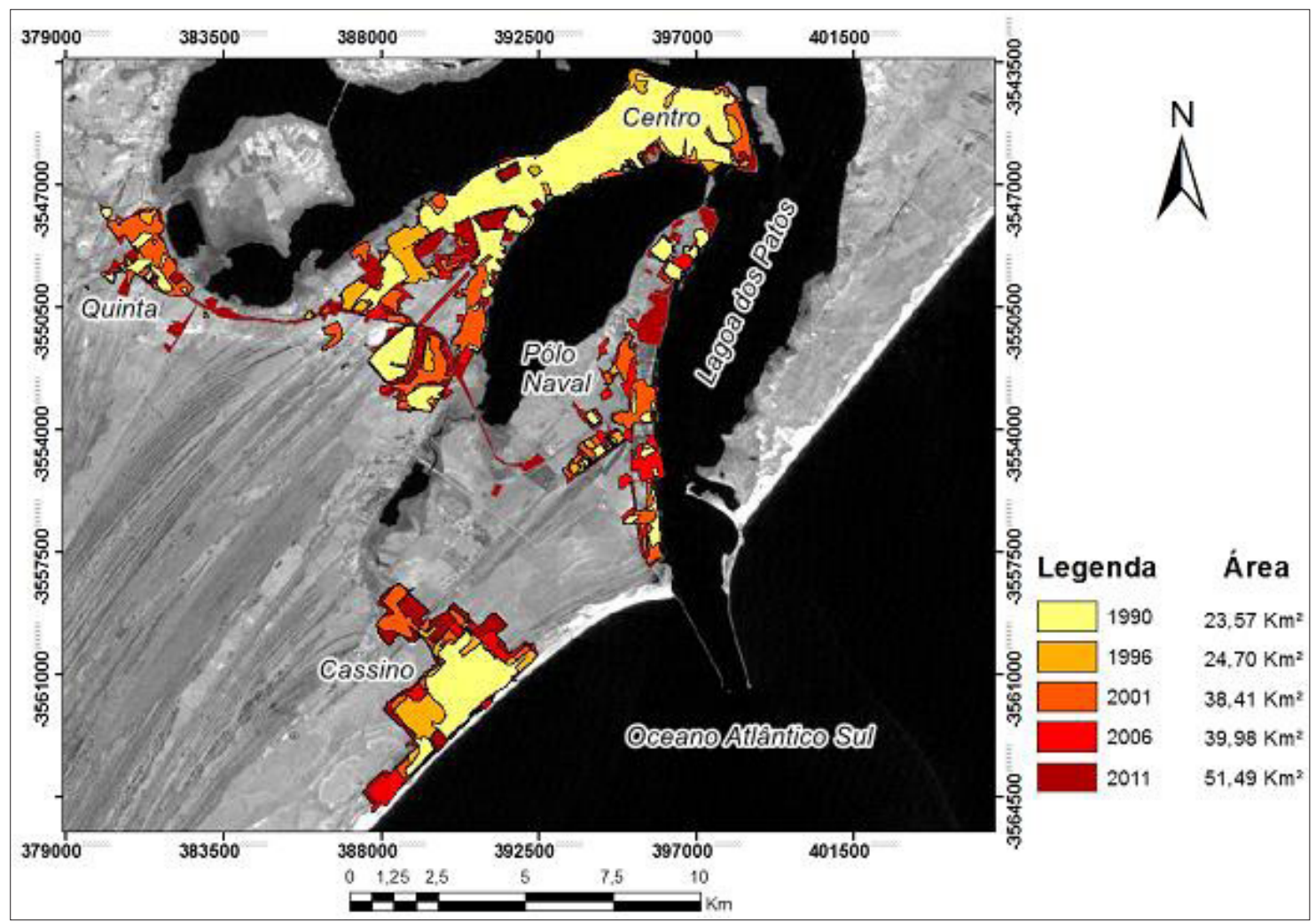

Fonte: Org. GALLO, B. B., 2014.

\section{São José do Norte}

No caso de São José do Norte, cidade localizada em frente à Rio Grande, (separada pelo canal que liga a Lagoa dos Patos ao oceano) a população urbana passa de 13.510 habitantes em 1991 para 16.617 em 2010 num total de 3.107 habitantes ou 22,3 \%. Já a renda per capta vai de $\mathrm{R} \$ 212,82$ em 1991 para $\mathrm{R} \$ 493,78$ em 2010. No que se refere à expansão a área urbana apresenta 0,7335 Km2 em 1990 e 2,7765 Km2 em 2011 num total de 2,043 km2 ou $278,52 \%$.) novamente no comparativo entre os dados do IBGE e o resultado da interpretação das imagens (Figura 6) foi confirmado o crescimento da cidade em questão. A expansão urbana neste caso é contínua a partir do núcleo principal. Podem-se constatar também a partir de dados da prefeitura municipal que, 70\% dos loteamentos da cidade são irregulares ou invasões, muitas delas em APPs, Áreas de Preservação Permanente, nesse caso específico, dunas, cuja população vem tanto do interior quanto de outras localidades a fim de trabalhar no pólo naval. Assim, mais uma vez é constatada a procura por terra periférica com menor valor agregado principalmente pela população com menor poder aquisitivo. 
De acordo com Marques (2008) houve no período violento êxodo rural para a sede do município (principalmente na periferia) fato esse proporcionado pela falta de energia elétrica, telefone,e serviços de saúde e educação. Além disso, a deficiência de acessibilidade, estradas em péssimo estado dificultam além da locomoção o escoamento da produção. A ocupação do solo ocorreu de forma desordenada e irregular. Atualmente, a Zona Urbana do Município se caracteriza pela ocupação de áreas de preservação, áreas de risco, em terrenos de marinha e áreas pertencentes ao Patrimônio da União, tais como orlada Laguna dos Patos e cômodos de dunas. A maioria dos imóveis são posses em loteamentos e ocupações irregulares, sem nenhum título de propriedade, em ruas abertas à própria sorte e sem infraestrutura básica. Cabe salientar que São José do Norte tem com Rio Grande uma relação de dependência econômica fato esse observado na sua configuração socioespacial ou nos seus bairros dormitórios. A perspectiva da construção de um terminal da Aracruz Celulose no município criou uma expectativa na população (MARQUES, 2008).

Figura 6 - Mapa resultante da vetorização do município de São José do Norte, sobreposta a uma imagem do sensor TM pertencente ao satélite LANDSAT 5

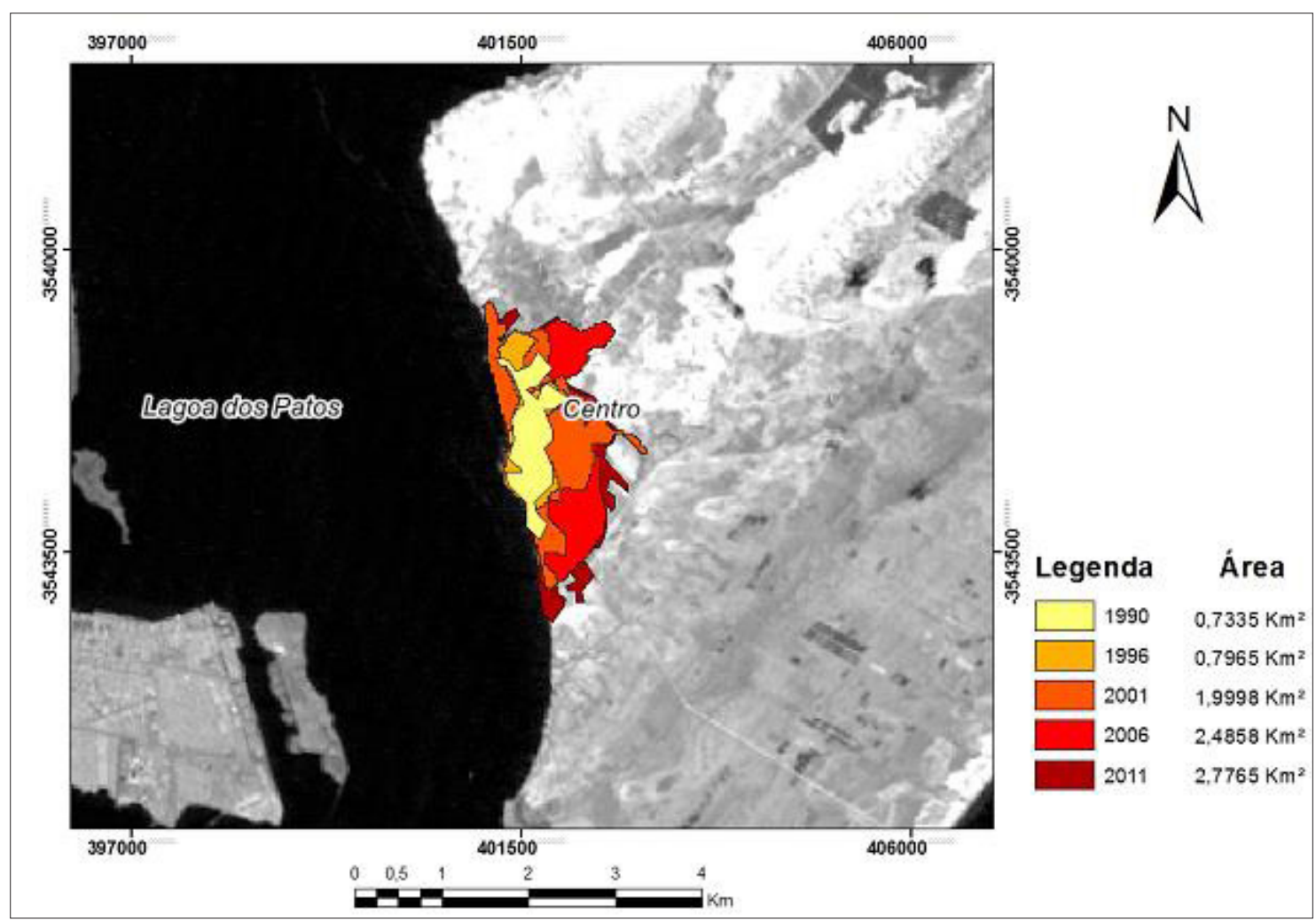

Fonte: Org. GALLO, B. B., 2014. 


\section{Arroio do Padre}

Para concluir tem-se o caso de Arroio do Padre, cujo núcleo tem características rururbanas e, sua área urbana apresenta 454 habitantes e no período não apresentou expansão. Como já expresso anteriormente configura uma forma urbana padrão "espinha de peixe" (Figura 7) Nesse caso, também a urbanização segue as vias de transporte, e o uso do solo está relacionado à ocupações formais não sendo observadas favelas no local.

Figura 7 - Mapa da cidade de Arroio do Padre

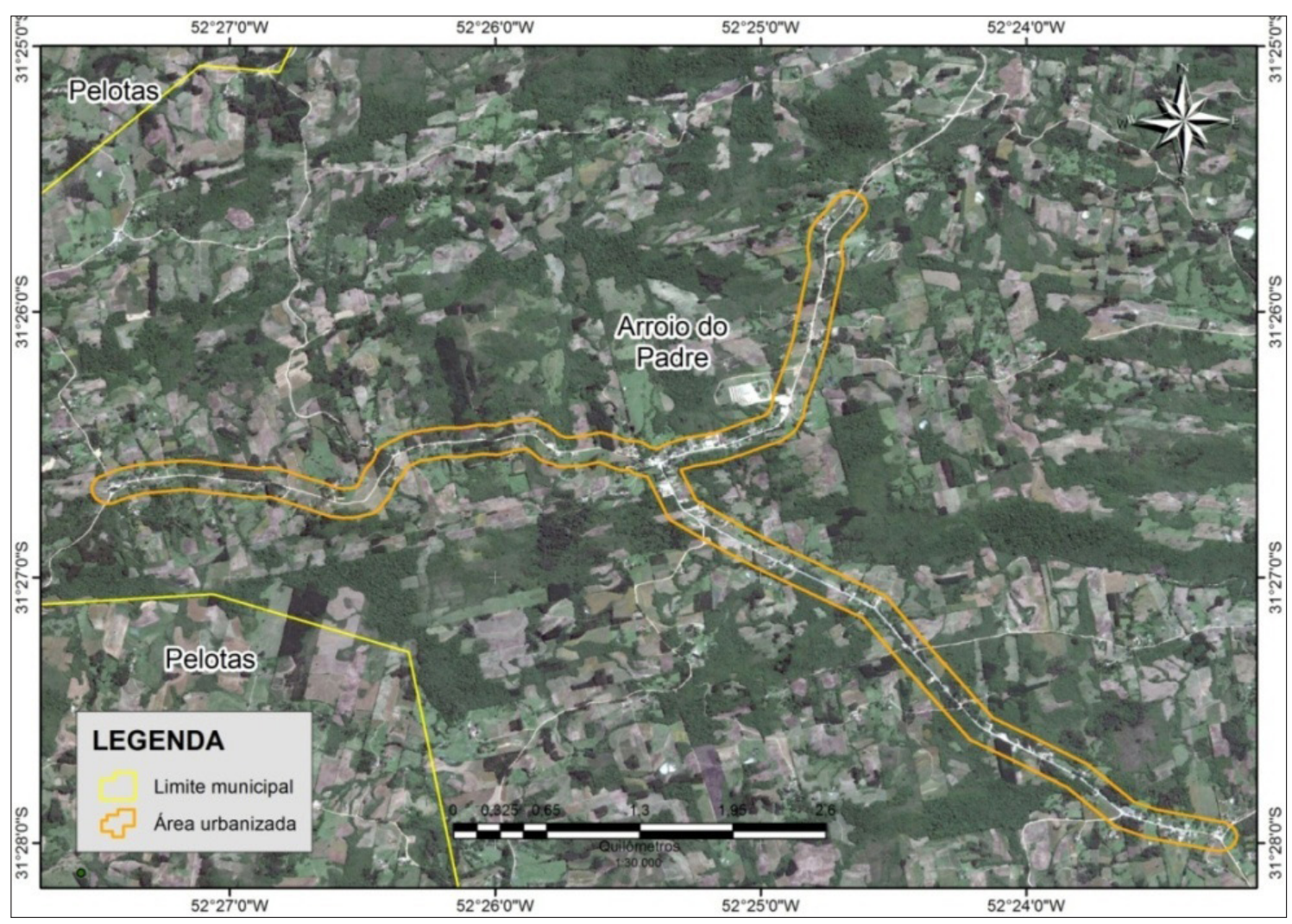

Fonte: Google Earth ${ }^{\circledR} 2011$

\section{EXPANSÃO URBANA NA AGLOMERAÇÃO URBANA DO SUL}

O processo de crescimento da Aglomeração Urbana do Sul analisado nesse trabalho através de dados sobre a população, econômicos e da expansão urbana no período de1990 a 2011 apresentaram as seguintes características:

Quanto ao aumento populacional, Pelotas apresentou maior indicador em termos de quantidade, 41.031, seguidas por Rio Grande 24. 404, Capão do Leão, 6.188, São José do Norte 3.873 já Arroio do Padre apresenta 454 pessoas em sua área urbana. (ver quadro 1 e 2). Quanto ao percentual, Capão do Leão e São José do Norte, ambas as cidades 
relacionadas com Pelotas e Rio Grande apresentaram maior percentual de crescimento $38,21 \%$ e $28,66 \%$ respectivamente. No que se refere ao IDHM (quadro 3) (Índice de Desenvolvimento Humano Municipal) observa-se em 1991 em alguns municípios, índices baixos semelhantes a países da África, no entanto já em 1990 esses índices tendem ao atual índice Brasileiro, um índice médio ou 0,755 na escala de 0 a 1.

Em termos de expansão da área urbanizada (quadro 4 e figuras 3,4,5 e 6) os dados obtidos foram os seguintes; Rio Grande obteve maior valor 27,92 Km2, seguida por Pelotas 20,3 Km2, Capão do Leão 16,46Km2, São José o Norte 2,043 Km2 e Arroio do Padre praticamente não apresentou expansão. Já os dados referentes ao percentual de crescimento correspondem a: Capão do Leão aparece em primeiro lugar com 642,9\% seguida de São José do Norte com 278,52\% Rio Grande118,45\% e Pelotas com 45,25\% Mais uma vez o maior percentual ocorreu nos municípios periféricos às cidades núcleo da aglomeração; Capão do Leão e São José do Norte o que pode ser explicado pelo fato de a terra periférica ter menor valor, Villaça (1998) nas cidades satélites da estrutura bipolar da aglomeração Rio Grande e Pelotas. Nesse caso é importante ressaltar também que Rio Grande foi a cidade que obteve maior percentual de aumento da área urbanizada enquanto Pelotas maior aumento populacional.

É necessário salientar também, que em todos os casos, a taxa de expansão da mancha urbana foi maior que a taxa de crescimento do número de habitantes da aglomeração o que pode ser observado nas tabelas abaixo que apresentam a síntese do aumento populacional e expansão da área urbanizada dos municípios da aglomeração.

Tabela 1 - População urbana nos municípios da AUSUL 1991 e 2011

\begin{tabular}{c|c|c} 
Cidade & $\begin{array}{c}\text { População Urbana } \\
\mathbf{1 9 9 1 ( h a b )}\end{array}$ & População Urbana 2010 (hab) \\
\hline Pelotas & 265.192 & 306.193 \\
\hline Capão do Leão & 16.194 & 22.382 \\
\hline Rio Grande & 165.025 & 189.429 \\
\hline São José do Norte & 13.510 & 17.383 \\
\hline Arroio do Padre & Sem dados & 454 \\
\hline
\end{tabular}

Fonte: Elaboração própria 
Tabela 2 - Aumento populacional nos municípios no período 1991-2010

\begin{tabular}{c|c|c} 
Cidade & $\begin{array}{c}\text { Aumento populacional } \\
\text { (hab) }\end{array}$ & $\begin{array}{c}\text { Percentual de Aumento } \\
\text { populacional }\end{array}$ \\
\hline Pelotas & 41.031 & $15,40 \%$ \\
\hline Capão do Leão & 6.188 & $38,21 \%$ \\
\hline Rio Grande & 24.404 & $12,88 \%$ \\
\hline São José do Norte & 3.873 & $28,66 \%$ \\
\hline Arroio do Padre & Sem dados & Sem dados \\
\hline
\end{tabular}

Fonte: Elaboração Própria

Tabela 3 - IDHM (Índice de Desenvolvimento Municipal)nos municípios da AUSUL 1991 e 2010

\begin{tabular}{ccc} 
Cidade & IDHM 1991 & IDHM 2010 \\
\hline Pelotas & 0,558 & 0,739 \\
\hline Capão do Leão & 0,413 & 0,637 \\
\hline Rio Grande & 0,527 & 0,744 \\
\hline São José do Norte & 0,36 & 0,623 \\
\hline Arroio do Padre & 0,319 & 0,669 \\
\hline
\end{tabular}

Fonte: Elaboração Própria

No referente à morfologia, no início do século XX as cidades latino americanas apresentavam uma estrutura compacta com uma área central definida que polarizava as funções urbanas de cada espaço da cidade. No entanto, a partir do processo de globalização elas passaram a ser mais descontínuas e fragmentadas num processo de urbanização de caráter difuso marcadas pela descontinuidade territorial (CABETTE, 2015).

Esse processo aconteceu também na Aglomeração urbana do Sul podendo ser identificado em Pelotas, Rio Grande e Capão do Leão e São José do Norte.

Nessas cidades, a formação dos vazios (ver figuras. 3, 4, 5 e 6) foi desencadeada pelo processo de fragmentação do espaço promovido, principalmente, pela expansão urbana, abertura de loteamentos, conjuntos habitacionais ocupação informal e o surgimento de novos eixos de centralidades como em Rio Grande a partir do pólo naval.

Esses vazios segundo Alvarez (1994,), Ebner (1997) se inserem na dinâmica de (re) produção da cidade e são o resultado da produção da cidade, uma vez que são espaços construídos, ou seja, houve um trabalho social em seu entorno, para que pudessem caracterizar-se como vazios. Nesses termos, tanto a cidade vazia como a construída fazem parte do mesmo processo; o da produção do espaço "uma vez que o terreno vago só se explica e justifica pelas circunstancia em que se insere" 
No Brasil, as discussões sobre os vazios urbanos aparecem relacionadas com o processo de expansão urbana capitalista, quando no ato de crescimento urbano as cidades expandiamse em direção as periferias, deixando, nos interstícios, terrenos e imóveis vazios, mantidos fora de mercado à espera da valorização imobiliária (SILVA, 2015).

Nesses termos comenta Campos Filho (2001) que uma das formas de manifestação da especulação imobiliária nas cidades brasileiras está relacionada com a retenção de imóveis vazios, especialmente terrenos. Segundo o autor, uma das formas desse procedimento é adquirir, a preço baixo, glebas próximas ao perímetro urbano, carentes de serviços urbanos, visando promover o seu loteamento de modo que a parte mais distante da área já urbanizada seja ocupada valorizando vazios intersticiais.

É no processo de ocupação do espaço que ocorre o fenômeno vazio urbano. O vazio urbano é a criação de espaço destinado à especulação. Ele atrela os interesses especulativos dos proprietários de terras urbanas e a estocagem de terra por parte dos produtores do espaço urbano. Nesse sentido, essas terras se tornam inacessíveis em termos monetários à maioria da população.

Assim, deve-se fazer referencia Faleiros (1983) e Santos (1994), o primeiro ao comentar que a especulação imobiliária possui importante papel na expansão urbana e de condições de vida para a população urbana e o segundo, ao fazer referencia que a especulação imobiliária é o resultado das formas pelas quais se realiza a acumulação do capital na produção da cidade, pois capital e propriedade se fundem nessa produção. Nesse contexto Kandir (1983) afirma que em economias capitalistas o solo urbano é importante ativo para a especulação.

Outro aspecto a levar em conta nesse caso estudado são as vias de transporte que constituem segundo Villaça (1998) o mais poderoso elemento na atração da expansão urbana. Já em 1992, Kowarick sugeriu que não poderia haver a periferização das cidades sem a alteração dos sistemas de transporte com expansão constante das franjas periurbanas. Nesse sentido, em todas as cidades a expansão urbana acontece partir da estruturação das vias de transporte fato esse relacionado à melhoria da acessibilidade e consequentemente sua valorização. Segundo Villaça (1998p.82)

o sistema interurbano de transporte, quando apresenta a possibilidade de oferecer transporte urbano de passageiros, atrai a ocupação urbana nos pontos acessíveis ou potencialmente acessíveis, visto que altera o valor de uso da terra, gerando uma oferta de novas localizações que são ocupadas por uma parte do excedente de população e atividades geradas a partir da cidade central(VILLAÇA,1998 p.82). 
Outro elemento que mais influencia a expansão urbana no sentido de obstrui-lo e, portanto adensar o tecido urbano são os obstáculos naturais (como é o caso de Rio Grande) tais como serras, zonas de proteção de recursos naturais, zonas pantanosas etc.

Mesmo desempenhando eventualmente um papel demográfica e territorialmente secundário, os atrativos do sítio natural têm constituído importante fator de atração da expansão urbana atraindo principalmente população de alta renda. Por essas características transformaram-se em traço típico da metrópole brasileira as orlas de alto mar. Villaça (1998) assim se expressa "a orla oceânica atua como fator a atrair a expansão antes de haver significativa melhoria do sistema de transportes regional e mesmo do local. No caso, núcleo que começou a se desenvolver ainda no início do século passado no o balneário Cassino (local de residências de veraneio de Pelotas e Rio Grande), atualmente importante balneário do litoral sul do Rio Grande do Sul o motor inicial foi a atratividade do sitio ou segundo (HARVEY,1985).

Deve-se fazer referencia também, a produção da cidade por loteamentos irregulares e ocupações informais. Exceto Arroio do Padre, que é uma cidade com características de vila rural, Pelotas, Rio Grande, São Jose do Norte e Capão do Leão apresentam esse tipo de configuração no processo de expansão urbana no período. E importante ressaltar aqui que as cidades satélites aos dois núcleos principais da aglomeração, São Jose do Norte e Capão do Leão apresentaram de modo intenso esse padrão de ocupação do solo, o que pode ser explicado pelo fato de a terra urbana periférica ter menor valor (VILLAÇA, 1998).

Por fim, vale ressaltar também a ocupação em áreas de preservação ambiental, dunas moveis em São Jose do Norte por loteamentos irregulares e invasões, e dunas no balneário Cassino. Nesse caso cita-se Maricato (2001) quando comenta que áreas ambientalmente frágeis e protegidas por lei são as mais agredidas pela falta de alternativas de moradia no mercado legal, para a maior parte da população das metrópoles e grandes cidades brasileiras sendo a questão imobiliária e fundiária está na base do travamento desse mercado. Já no caso de Pelotas A expansão em área de Preservação do Ambiente Natural se deu a leste por loteamentos formais ocupando também área de dunas e mata (últimos vestígios da mata Atlântica do sul do Brasil) (PARFITT, 2016).

\section{CONSIDERAÇÕES FINAIS}

A partir de uma análise inicial observa-se que as transformações socioterritoriais da região que compreende a Aglomeração Urbana do Sul fazem parte de um processo com tendências tanto de concentração, quanto dispersão. 
No período de 1990 a 2011 houve na estrutura urbano-regional da Aglomeração sensíveis transformações a partir do estabelecimento de nova infraestrutura que veio a dinamizar o território com a implementação de novas atividades produtivas, bem como novos empregos. A Aglomeração Urbana do Sul tornou-se no período um território dinâmico com a inserção de novas de atividades vinculadas a cadeias produtivas globalizadas.

A urbanização que acompanhou a criação do Polo Naval a partir de 2006 arregimentou grandes contingentes de pessoas que se refletiu em Rio Grande em particular e na aglomeração como um todo. Portanto a inserção de grandes empresas vinculadas a processos de internacionalização do capital proporcionou uma nova estruturação socioterritorial. Nesse contexto, o fenômeno urbano não pode ser compreendido sem levar em conta a questão regional.

Principalmente nas cidades satélites aos núcleos da região ou Capão do Leão e São José do Norte houve constante estímulo para expansão urbana por loteamentos irregulares ou invasões, pelo fato da terra apresentar menor valor.

A ocupação do espaço urbano relacionada à urbanização acarretou a formação de assentamentos ilegais, caracterizados pela ocupação informal e por contarem com população assentada em áreas precárias.A expansão da área urbanizada foi possível em boa medida, a partir da infraestrutura, no caso os sistemas de transporte. Nesse sentido, em todas as cidades estudadas a expansão urbana acontece partir da estruturação das vias de transporte, fato esse relacionado à melhoria da acessibilidade e consequentemente sua valorização. Podese relacionar o fenômeno da expansão também com os atrativos do sítio como no caso do balneário Cassino em Rio Grande e a expansão de Pelotas a leste em direção à lagoa dos Patos.

Para concluir, deve-se fazer referencia também ao fenômeno dos vazios urbanos, (espaços destinados à especulação) atrelados ao processo de expansão que ocorrem em Pelotas, Rio Grande, Capão do Leão e Arroio do Padre.

\section{REFERÊNCIAS}

1. ABRAMO, P. Mercado e ordem urbana. Rio de Janeiro: Bertrand Brasil, 2007.

2. ABRAMO, P. A cidade com- fusa a mão inexorável do mercado e a produção da estrutura urbana nas grandes metrópoles Latino- Americanas. R. B.de Estudos Urbanos e Regionais.v.9,n.2, nov.2007.

3. BRASIL, Lei de Loteamentos.Lei 6766 de dezembro de 1979.

4. ALVAREZ, Ricardo. Os vazios urbanos e o processo de produção da cidade. Dissertação (mestrado em geografia). Programa de Pós-graduação em Geografia, USP 1994. 
5. BRAGA, R. Cidades médias e aglomerações urbanas no estado de São Paulo: Novas estratégias de gestão territorial. Anais... X Encontro de Geógrafos da América Latina São Paulo,2005.

6. CABETTE, A. Dinâmica demográfica e a produção imobiliária em Porto Alegre RS.Dissertação de mestrado em Geografia, Porto Alegre, UFRGS, 2015.

7. CARlOS, A. F. A. A (Re) Produção do Espaço Urbano. São Paulo: Edusp, 2008.

8. CAMPOS FILHO, Candido Malta. Cidades Brasileiras, seu controle ou o caos. São Paulo: Nobel, 2001.

9. DOMINGUES, M. V. D. L. R. Desenvolvimento e Consolidação do Pólo Naval e Offshore de Rio Grande. 2009. SEDAI, S. D. A. I.-. 396 p.

10. DAVIDOVICH, Fanny Rache; LIMA, Olga M. Buarque de.Contribuição ao estudo de aglomerações urbanas no Brasil.Revista Brasileira de Geografia. Rio de Janeiro,a. 37, n. 1, 1975. p. 50-84.

11. DOMINGUES, et.al. Planejamento urbano em áreas inundáveis de um município costeiro:estudo de caso em Rio Grande RS Brasil.Costas,v1,n1,2012.

12. DOMINGUES, M. V. D. L. R.Desenvolvimento e Consolidação do Pólo Naval e Offshore de Rio Grande.2009. SEDAI, S. D. A. I.-. 396 p.

13. EBNER, Iris de Almeida Rezende. Vazios Urbanos: uma abordagem do ambiente construído. 1997. 217f. Dissertação (mestrado em estruturas ambientais e urbanas). Programa dePósgraduação da Faculdade de Arquitetura e Urbanismos. USP. São Paulo, 1997.

14. FALEIROS, H. A. Expansão urbana e especulação imobiliária. São Paulo: PUC-SP, 1983

15. HARVEY,D. The urbanization of capital.Oxford: Blackwell,1985.

16. KANDIR, A. A instabilidade do mercado habitacional. IE: UNICAMP, Dissertação de mestrado. Campinas, 1983

17. KOWARICK, L. "La crisis urbana y laciudadaníaen São Paulo". En Ciudades y políticas urbanas, compilado por Fernando Carrión, 17-29. Quito: Codel, 1992

18. MAIA,D.S. A periferização e a fragmentação da cidade loteamentos fechados conjuntos habitacionais populares e loteamentos irregulares na cidade de Campina Grande PB Brasil. Revista Scripta Nova,v.XlV,n. 331,2010.

19. MARICATO,E. Urbanismo na periferia do mundo globalizado: metrópoles brasileiras.São Paulo Perspec. vol.14 n.4 São Paulo Oct./Dec. 2000

20. MARICATO, E. Brasil, cidades: alternativas para a crise urbana. 2. ed. Petrópolis: vozes, 200.

21. MAMMARELLA, R.; BARCELLOS, T. M. de. O fenômeno aglomerativo no Rio Grande do Sul: panorama atual. Indicadores Econômicos FEE, Porto Alegre, v. 36, n. 3, p. 117-136, 2008.

22. MARQUES,C.B. O processo de urbanização e as nuances do desenvolvimento local- São José do Norte- Brasil. $1^{\circ}$ Congresso de Desenvolvimento Regional de Cabo Verde, Anais... 2008. 
23. MATOS, Ralfo. Aglomerações urbanas, rede de cidades e desconcentração demográfica no Brasil. In:Encontro de Estudos Populacionais, 12., 2000,Caxambu. [Anais...]. [Caxambu : ABEP, 2000]. v. 1,Disponível em:http:<//www.abep.nepo.unicamp.br/docs/anais/pdf/>. Acesso em: 4 de setembro de 2016.

24. MOURA, R.; ULTRAMARI, C. (org) Metrópole: grande Curitiba, teoria e prática. Curitiba: Ipardes, 1994, p.123-136.

25. MOURA, R. Movimento pendular e perspectivas de pesquisas em aglomerados urbanos. São Paulo Perspec. vol.19 no.4 São Paulo Oct./Dec. 2005

26. MYAZAKI, V. O processo de aglomeração urbana:um estudo sobre Presidente Prudente e Álvares Machado no estado de São Paulo,Brasil, Scripta Nova, volIX n.194,2005.

27. OJIMA, R. Dimensões da urbanização dispersa e proposta metodológica para estudos comparativos: uma abordagem socioespacial em aglomerações urbanas brasileiras. Revista Brasileira de Estudos da População. São Paulo: v. 24,n.2, p 277-300,2007.

28. PARFITT, C.M. Áreas de preservação do ambiente natural urbano, segregação e impacto nas paisagens e na biodiversidade: estudo de caso de Pelotas R.S. Revista ,Raega- o espaço geográfico em análise v.37, 2016.

29. PRADILLA, E. Contribución a la crítica de la teoría urbana. Del espacio a la crisis urbana. México, D.F.: Editorial Universidad Autónoma Metropolitana 1984.

30. RAMOS, E. MATOS, R. As cidades médias como nódulos de equilíbrio da rede de cidades. Revista Paranaense de Desenvolvimento, Curitiba, n.121, p.41-63, jul./dez. 2011

31. REDWOOD, John. Reversion de polarizacion, ciudades secundárias y eficiência em eldesarrollo nacional: uma vision teórica aplicada al Brasil contemporâneo. Revista Latino americana de estúdios urbanos regionales, Santiago:v,n.32.dez 1984.

32. REOLON, C.A. Aglomeração urbana da soja: Cascavel e Toledo no contexto da metropolização da Mesorregião do Oeste Paranaense. Dissertação ( Mestrado em Desenvolvimento Regional) Universidade Estadual do Oeste do Paraná (UNIOESTE) 2007.

33. RIBEIRO, L.C.Q. Dos cortiços aos condomínios fechados: as formas de produção da moradia na cidade do Rio de Janeiro. Rio de Janeiro: Civilização Brasileira IPPUR/UFRJ,1997.

34. SANTOS, M. Urbanização brasileira. São Paulo: Hucitec, 1994.

35. SANTOS, M. Manual de geografia urbana. São Paulo: HUCITEC, 1981

36. SASSEN, S. As cidades na economia mundial. São Paulo: Studio Nobel,1998.

37. SILVA, P.J. da Vazios urbanos e a dinâmica imobiliária na produção do espaço em Natal, R.N.Dissertação de mestrado,UFRN,Natal,2015.

38. SOARES, Maria Therezinha de Segadas. Critérios para delimitação de áreas metropolitanas e a possibilidade de sua aplicação ao Brasil. In: Simpósio de Geografia Urbana, 1.: 1966, Buenos Aires. Anais... Rio de Janeiro: Instituto Pan-Americano de Geografia e História / Comissão de Geografia, 1968. p. 91-106. 
39. SOARES, P.R. Novos recortes territoriais e aglomerações urbanas no sul do Brasil.Barcelona, Revista Scripta Nova,v.X,n.194, 2005.

40. SOUZA, M. J. L. de. O ABC do desenvolvimento urbano. 2 ed. Rio de Janeiro:Bertrand Brasil, 2005.

41. UN- HABITAT. Operational definitions for household Surveys in Cities on cure Tenure e Slums,2002.

42. WEIMER, G. Origem e evolução das cidades Rio-Grandenses. Porto Alegre: Livraria do Arquiteto, 2004

ARTIGO RECEBIDO EM MAIO DE 2017

ARTIGO ACEITO EM JUNHO 2017 